\title{
The Relationship between Metacognition and Self-Regulation on Civics Subject Class Xi Ips-1 Sman 1 Cerme
}

\author{
Fatah Yasin \\ State University of Surabaya \\ fatahyasin190861@gmail.com \\ Rusijono \\ State University of Surabaya \\ rusijono@unesa.ac.id \\ Bachtiar Syaiful Bachri \\ State University of Surabaya \\ mustaji@unesa.ac.id \\ Fajar Arianto \\ State University of Surabaya \\ fajararianto@unesa.ac.id
}

\begin{abstract}
This study aimed to determine the relationship between self-regulation and metacognition and students on subjects civics. The study was conducted in three phases: the first phase of developing the research instruments, and then test the research instrument with a limited sample to look for the validity and reliability instruments. The third stage testing of the instrument that has proven the validity and reliable in class XI IPS-1 SMAN 1 Cerme. The draft implementation in the classroom used pretest and posttest design and data analysis in qualitative descriptive. Based on the analysis, the study showed that the correlation between variables metacognitive against self-regulated learning of students in the material administration Civics subject obtained correlation index $r_{x y} 0,799$ so the correlation is strong. As well as great influence on the students' metacognition self-regulated learning, the value of $r 2$ of 0.638. Then the value is multiplied by $100 \%$ to determine the influence in a value. Thus percent influence obtained value of the of students' metacognition influence on self-regulated learning of students $63.8 \%$.
\end{abstract}

Keyword: metacognition, self-regulation.

\section{Introduction}

Improving quality of education they have implemented is requirement of each institution. One indicator of educational quality improvement can be seen by increasing of student learning outcomes. If the results of student learning are good, it can be said the quality of education at the school is good, and vice versa. In an effort of increasing the learning outcomes are by understanding the concept, psychomotor, and affective, teachers are required to raise students' motivation. Due to successful students in learning is the term motivate students to learn. It can be seen by cognitive development.

While cognitive development is considered as a determinant of children's intellect, cognitive abilities continue to grow along with the educational process and also influenced by the physical development of the brain primarily biological Subsequent developments related to cognitive is how to manage or regulate the cognitive ability to respond to situations or problems. Obviously, cognitive aspects cannot walk alone in isolation but need to be controlled or blood money so that if someone is going to use his cognitive abilities it needs the ability to define and regulator of cognitive activity that will be used. Therefore, someone must have an awareness of their own capacity to think and to be able to arrange it. Experts say this is called the metacognitive ability.

Flavell and Brown in Velzen (2016) stated that metacognition is knowledge (knowledge) and regulations (regulation) on a person's cognitive activity in the process learning. While Moore (2014) states that: Metacognition refers to one's understanding of knowledge, so that a deep understanding of knowledge will reflect the effective use or a clear description of the knowledge in question. This indicates that the knowledge-cognition is a person's consciousness about what is actually known and regulation-cognition is how one regulates the activity cognitive effectively. 
Therefore, knowledge-cognition includes declarative knowledge, procedural, and conditional, being regulatorycognition includes planning, prediction, monitoring (monitoring), testing, repair (revised), checking (inspection), and evaluation. Based on the understanding of metacognitive of experts concluded that metacognitive is an awareness of our own cognitive, cognitive how we work and how to organize it. This capability is particularly important for the purposes of our cognitive efficiency in solving the problem. Briefly metacognitive can be termed as Thinking about thinking".

Optimal development in all aspects of a child is a success factor in the future. Parenting and education conducted by parents, teachers and the environment will affect the quality of the child. Without ignoring other aspects cognitive development becomes an important focus in addition to physical development in childhood. Along with improved cognitive ability, the child begins to realize that the mind is separate from the objects or actions.

Children are able to begin to organize his thoughts in a simple form. Based on research Flavel, children 3 years old have the ability to organize his thoughts Ability is called metacognitive, is an awareness of our own cognitive, cognitive how we work and how to organize it. This capability is particularly important for the purposes of our cognitive efficiency in solving the problem. Briefly metacognitive can be termed as "thinking about thinking" Students can use metacognitive strategies in learning ensuing includes three stages, namely: designing what you want to learn, monitor progress in learning; and assess what is learned. Metacognitive strategies can be applied to any field of study learning. It is important to direct them in order to consciously control the thinking process in learning.

Indicators of metacognitive skills to be developed are: (1) identify the task at hand, (2) to supervise the work progress, (3) evaluate this progress, and (4) predict the results that will be obtained. Furthermore, the processes aimed at setting the thinking process will also help (1) allocate resources-owned resources to perform tasks, (2) define the steps of task completion, and (3) determine the intensity, or (4) speed in completing the task. The indicators are set forth in metacognitive skills inventory skill metacognitive. A strategy to develop metacognitive skills are as follows, (1) identifying "what you know" and "what you do not know", (2) discussing about thinking, (3) Journaling planning and self- regulation, (4) explaining the thought process and evaluation (Lauca, 2008).

Josyula, Franklin, Harish, Bette, Fassil, Michelle, Jalissa, Ahmed \&Chinomnso in their research (2013) stated that selfregulated learning refers to the ability of an agent to be able to determine when to learn, what to learn, and how to learn. Knowing when to learn requires an ability to judge when to start and stop learning. Knowing what to learn requires an ability to identify the specific piece of knowledge that is lacking. Knowing how to learn requires an ability to choose the best learning strategy availableto learn what is required.

Several studies have shown that self-regulated learning related to or affecting the learning achievement. As research conducted by Tzohar-Rozen (2013) with title Metacognition, Motivation, and Emotions: Contribution of Self Regulated Learning to Solving Mathematical Problems. The research results proved the existence of a relationship between self-regulated learning and academic achievement in Mathematical problem. In that study, self-regulated learning of students is high. This is in line with the student achievement. Students who have self-regulated learning high followed by high academic achievement as well. Likewise, students who have low self-regulated learning achievement followed low. This happens because the students who have high self-regulated learning is able to choose different learning strategies for each subject. The strategy also vary depending on different difficulty levels so as to improve the student's academic pre outstations.

According Boyd, Barnett, Bodrova, Leong, \&Gomby, (2005) defines self regulated learning as the ability to manage one's behavior, so as to withstand, impulses, maintain focus, and undertake tasks, even if there are other more enticing alternatives available. The definition indicates that self-regulated learning is a self-monitoring process of designing and careful review of the cognitive and affective processes in completing an academic task. Furthermore Bandura suggests three steps in implementing self-regulated learning namely: (1) Observe and supervise themselves. (2) Comparing the denviable position with a certain standard. (3) Provide own response (a positive response and negative response) of various sense of self-regulated learning can be concluded that Self-regulated Learning is an attempt to set a goal in the learning process in a way to monitor, regulate, and control aspects of cognition, motivation, and behavior. The whole process will be directed and driven by purpose and customized environmental context.

\section{Method}

The method used in this research is descriptive correlational method using a quantitative approach, which describe the relationship of metacognitive and self- regulation in students. A descriptive research is research that seeks to describe a phenomenon, events, events that occur at the present time. This research approach is used to test the hypothesis test set. Quantitative research method is explaining phenomena by collecting numerical data that are analysed using mathematically based methods (in particular statistic)(Aliaga and Gunderson, 2005). 
Table 1. The relationship between metacognitive and self-regulation

\begin{tabular}{|c|c|c|c|c|c|}
\hline & \multicolumn{4}{|c|}{ Self-regulation (Y) } \\
\hline & & $\begin{array}{l}\text { Allocate } \\
\text { resource- } \\
\text { owned } \\
\text { resources }\end{array}$ & $\begin{array}{c}\text { Comparing } \\
\text { self } \\
\text { position } \\
\text { with } \\
\text { certain } \\
\text { standards }\end{array}$ & $\begin{array}{l}\text { Determine } \\
\text { the intensity }\end{array}$ & $\begin{array}{l}\text { Speed in } \\
\text { completing } \\
\text { the task }\end{array}$ \\
\hline \multirow{4}{*}{$\begin{array}{l}\text { Metacognitive } \\
\text { (X) }\end{array}$} & $\begin{array}{c}\text { Identifying } \\
\text { the task at } \\
\text { hand }\end{array}$ & & & & \\
\hline & $\begin{array}{l}\text { Supervise the } \\
\text { work } \\
\text { progress }\end{array}$ & & & & \\
\hline & $\begin{array}{l}\text { Evaluate } \\
\text { progress }\end{array}$ & & & & \\
\hline & $\begin{array}{l}\text { Predict the } \\
\text { results to be } \\
\text { obtained }\end{array}$ & & & & \\
\hline
\end{tabular}

According Bless and Higson-Smith (2000: 85) a population is "the set of elements that the research focuses on and to which the obtained results should be generalized". The population in this study were all students of class XI IPS SMAN1 Cerme. While the sample is first class XI IPS-1 SMAN 1 Cerme.

The techniques of data collection used by the author is as follows: (1) Interview (Interview) is methods of data collection through face to face and question and answer directly between interviewers (data collectors) and respondent (source data). (2) Observation is a method of collecting data through observation and recording by the data collector for the symptoms / events that were investigated in the research object.

In this study, data collection techniques that writers use to get data or information from the first party (respondent) to answer formulation of the problem that has been set before, the authors used a questionnaire as an instrument of data collection. Questionnaire is the author of the spread as much as 30 questionnaire. Where the questionnaire authors are scattered questionnaire closed model, in the sense that the respondent simply choose the option that has the author provided in the questionnaire. In the questionnaire that the author interchanges consists of eight statements to the variables $\mathrm{X}$ and seven statements to the variable $\mathrm{Y}$. Where to find out whether or not valid data with the instruments of each item being measured. After the completed questionnaires distributed and data has been collected, the next step is to do the tabulation, which provides value (scoring) in accordance with the specified item. Scoring is done by using a Likertscale 5-4-3-2-1. According RensisLikert (1932) "Likert scale is a psychometric scale that is commonly used in questionnaires and is the scale most widely used in research in the form of surveys".

With Likert scale, then the variable to be measured are translated into indicator variables. Then indicators are used as a instruments which can be a statement or a starting point to construct items question. Answer each item instrument that uses a Likert scale has gradations from very positive to very negative, which may include words such as:

Table 2. Score Top Answer Questionnaire

\begin{tabular}{|c|c|c|}
\hline No. & Type Answer & Score \\
\hline 1 & Strongly agree & 5 \\
\hline 2 & Agree & 4 \\
\hline 3 & Doubtful & 3 \\
\hline 4 & Disagree & 2 \\
\hline 5 & Strongly disagree & 1 \\
\hline
\end{tabular}

(Source: RensisLikert, 1932)

Having done tabulation, then the data is ready to be processed with quality test data through validity and reliability in order to know whether or not valid measuring instruments with the measured and least reliable measuring instrument when used in the future. Having done tabulation, then the data is ready to be processed with quality test data through validity and reliability in order to know whether or not valid measuring instruments with the measured and least reliable measuring instrument when used in the future. 
This validity test aims to assess the extent of the measuring instrument, in this questionnaire measure what is going to be measured, or the extent to which a measuring tool that is in use on target. The higher the validity of a test tool, then the tool is getting hit on target, or show what should be measured. Testing the validity of which is applied by the authors is the factor analysis, is by correlating the item scores between instruments within a factor, and factor scores correlate with a total score.

Correlation test is to see the relationship of the two measurement results or the two variables studied, to determine the degree of relationship between variable $\mathrm{X}$ to variable $\mathrm{Y}$. The reason of researchers used a technique Pearson product moment correlation. Reason researchers using this technique because the data obtained in the form of interval data obtained from the instrument using a Likert type scale. The formula used is:

$$
r_{x y}=\frac{\sum x y}{\sqrt{\left(\sum x^{2}\right)\left(\sum y^{2}\right)}}
$$

(Source: ASTM, 2012)

The correlation between the basic design parameters was described using simple correlation test. This test is a statistical technique which is used to measure the relationship level between 2 variables and the shape of their relationship. The relationship level is stated in number wherein bigger number shows stronger relationship (Table 3)(ASTM, 2012).

Table 3. Guidance of the correlation efficientinterpretation

\begin{tabular}{|c|c|}
\hline Interval coefficient & The level of relations \\
\hline 0.000 to 0.199 & Very weak \\
0.200 to 0.399 & Weak \\
0.400 to 0.599 & Moderate \\
0.600 to 0.799 & Strong \\
0.800 to 0.1000 & Very strong \\
\hline
\end{tabular}

Regression analysis was used to examine the relationship between two variables or more particularly to explore the relations that the model is not known completely, or to find out how the variation of some of independently affect the dependent variable in a complex phenomenon.

\section{Results And Discussion}

Before instruments distributed to the respondents, first conducted trials of the instrument. The test instrument is performed to determine whether the items on the questionnaire that it meets quality good instrument or not. The tools used in analytical testing trials include instrument validity and reliability test. Validity of instruments is done, by spreading data instruments to students at SMAN 1 Cerme. This validity test is used to determine the valid and whether grain instrument.

Beads of invalid instrument discarded. While valid instruments will be used to acquire data. The results of the analysis of the validity of the calculation of the grains instruments consulted with prices criticismr product moment, with a5\% error level. When the price $r_{x y}>r_{\text {table }}$ the grain of such instruments as valid, otherwise if the price $r_{x y}>r_{\text {table }}$ the grain of such instruments is said to be invalid.

Table 4. Percentage validity scale grain metacognition and self-regulated learning first stage

\begin{tabular}{|c|c|c|c|c|}
\hline No. & Criteria & No. grain & Amount & Percentage \\
\hline 1 & Valid & $\begin{array}{c}1-7,9,11-13,15,18-20,22-24, \\
31-33,35,37-39,41,42 .\end{array}$ & 30 & $71.43 \%$ \\
\hline 2 & No valid & $\begin{array}{c}8,10,14,16,17,21,25,29,30, \\
34,36,40 .\end{array}$ & 12 & $28.57 \%$ \\
\hline 3 & Total & 42 & $100 \%$ \\
\hline
\end{tabular}

Furthermore, items that have been valid is tested again to reduce the error rate at the time of testing. And test the validity of the second got the following results: 
Table 5. Percentage Validity Scale Grain Self-Regulated Learning Stage Two

\begin{tabular}{|c|c|c|c|c|}
\hline No. & Criteria & No. grain & Amount & Percentage \\
\hline 1 & Valid & $\begin{array}{c}1-7,9,11-13,15,18-20,22-24, \\
31-33,35,37-39,41,42 .\end{array}$ & 30 & $100 \%$ \\
\hline 2 & No valid & - & 0 & $0 \%$ \\
\hline 3 & Total & & 30 & $100 \%$ \\
\hline
\end{tabular}

After the validity test is completed, the next is the reliability test on the instrument. Reliability test is used to determine the level of consistency or a consistent answer remains to be tested at any time such instruments are presented.

Prices $r_{11}$ obtained consulted with price $r_{\text {table }}$ product moment with significance level of $5 \%$. Problem said to be reliable if the price $r_{11}>r_{\text {table }}$, From the calculation of the reliability values of test instruments item scale of self- regulated learning $r_{11}=0.86$, with a significance level $5 \%$ and $n=33$ obtained $r_{\text {table }}=0.355$ as compared with $r_{\text {table }}$ turns $r_{\text {count }}>r_{\text {table }}$. Because $r_{11}>r_{\text {table }}$ means the reliability coefficient of the test items have reliable testing criteria. So that the grains of grain-scale instruments metacognitive and self-regulated learning can be used.

Regression analysis was performed to determine the functional relationship between variables with a variable metacognitive self-regulated learning, so do the approximate score achievement students learn civics if known scores on self-regulated the metacognitive students contribute to the self-regulated learning, need to be sealed correlation test is then followed by simple regression.

From the analysis of data obtained as follows:

$$
\begin{array}{ll}
\mathrm{X}=86.29 & \mathrm{Y}=83.68 \\
\sum \mathrm{X}=2675 & \sum \mathrm{Y}=2594 \\
\sum \mathrm{X}^{2}=233367 & \sum \mathrm{Y}^{2}=218136 \\
\sum \mathrm{XY}=158 & \mathrm{~N}=31
\end{array}
$$

The procedure whether the principal is in regression of the predictors with the score of this deviation is: (1) for the relationship between predictors $(\mathrm{X})$ with criterion $(\mathrm{Y})$. The correlation between the predictor $\mathrm{X}$ with $\mathrm{Y}$ criterion can be searched through the Pearson product moment correlation technique, according to the formula:

$$
\begin{gathered}
r_{x y}=\frac{n\left(\sum X_{i} Y_{i}\right)-\left(\sum X_{i}\right)\left(\sum Y_{i}\right)}{\sqrt{\left(n \sum X_{i}^{2}-\left(\sum X_{i}\right)^{2}\right)\left(n \sum Y_{i}^{2}-\left(\sum Y_{i}\right)^{2}\right)}} \\
r_{x y}=\frac{31(225158)-(2675)(2594)}{\sqrt{\left(31 \times 233367-(2675)^{2}\right)\left(31 \times 218136-(2594)^{2}\right)}} \\
r_{x y}=0.799
\end{gathered}
$$

Based on the above calculation can be seen correlation index amounted $r_{x y}=0,799$ to provide interpretation of the correlation coefficients found large or small, can be seen in Table 2. Based on the correlation between the variables metacognition and self-regulated learning of students in the materials administration I Civics class X IPS-1 SMAN 1 Cerme, obtained correlation index $r_{x y}=0,799$ so the correlation is strong.(2) Test whether the relationship special or not, having conducted correlation product moment correlation, then result that obtained consulted with $r_{\text {table }}$ at a significance level of 5\% with the following assumptions:

If $r_{x y}>r_{\text {table }}$ means significant meaning hypothesis is accepted.

If $r_{x y}>r_{\text {table }}$ meansinsignificant means the hypothesis is rejected.

From the results of the test product moment correlation is known that $r_{x y}=0,799$ means significant meaning that the hypothesis is accepted, because $r_{x y}=0,799>r_{\text {table }}=0.355$ at significance level of $5 \% r_{x y}=0,799>r_{\text {table }}=0,456$ at $1 \%$ significance level. If the calculation results $\mathrm{r}_{\mathrm{xy}}$ percent $(\%)$, then, becomes $79.9 \%$. In this case means there is a significant relationship of metacognitive influence on self-regulated learning $79.9 \%$.

(3) Analysis of the regression line equation this analysis is used to find the relationship between the criteria with a predictor use the regression formula of the predictor score deviation.

\begin{tabular}{|ll|}
\hline $\begin{array}{l}\text { Significance } \\
\text { test }\end{array}$ & $\begin{array}{l}\text { Retrieved } \mathrm{F} \text { count }=51.08 \text { and table } \mathrm{F}=4.18 ; \text { Since } \mathrm{F} \text { arithmetic }=51.08> \\
4.18, \text { then the conclusion coefficient means. }\end{array}$ \\
\hline Linearity test & $\begin{array}{l}\text { Retrieved } \mathrm{F} \text { count }=1.07 \text { and table } \mathrm{F}=2.33 ; \text { Since } \mathrm{F} \text { arithmetic }=1.07< \\
2.33, \text { then the conclusion cobtained regression is linear regression. }\end{array}$ \\
\hline
\end{tabular}


These results indicate that the regression equation to the test class can be used to predict scores on self-regulated learning Civics test class with a score (in this study interval score is $30 \leq$ skor $\mathrm{SRL} \leq 120$ ).

From the results of the study in SMAN 1 Cerme showed no positive between metacognitive level possessed by learners towards self-regulated learning in Civics. It is caused by several factors, including: (a) Students who learn by metacognitive will be able to organize themselves in learning and be able to manage an environment conducive to learning self-regulation (self-in regulated learning).(b) They are increasingly interested in studying Civics because it believes that Civics become easier and more fun to learn because it is very close to life. In the end, students feel that the Civics have value for their day-to-day, not only provides the relevant issues in the real world. (c) The method of metacognitive students can determine a strategy that fits with the learning situation faced nor self-regulated learning students are able set himself in learning and so aimlessly satisfactory academic achievement.

From the above description shows that metacognition as a variable $\mathrm{X}$ has a significant influence on self-regulated learning as a variable $\mathrm{Y}$ That is between metacognition and self-regulated learning make a significant contribution in learning Civics. Students studying metacognition-based method can provide a good impact on the students' selfregulation.

This is also evidenced by the line of linear regression equation is $y=38,81+0,52 x$; Meanwhile the results of the regression analysis of variance obtained $\mathrm{F}$ value of $51.08 \mathrm{reg}$. Then these values consulted with $\mathrm{F}$ table, the significant level of $5 \%$ obtained a value of 4.18 Because the price of the $F_{\text {reg }}>F_{\text {table, }}$, then the regression line showed significant. This means that the null hypothesis $\left(\mathrm{H}_{0}\right)$ with a resounding "No influence students' metacognition towards selfregulated learning in class XI IPS-1 SMAN 1 Cerme" rejected. While working hypothesis $\left(\mathrm{H}_{\mathrm{i}}\right)$ which states "There are students' metacognition influence on self-regulated learning in class XI IPS-1 SMAN 1 Cerme" acceptable.

While searching the influence of students' metacognition towards self- regulated learning, the value of r 2 of 0.638 . Then the value is multiplied by $100 \%$ to determine the influence in a percent value. Thus obtained value of the influence of students' metacognition influence on self-regulated learning in class XI IPS-1 SMAN 1 Cerme 63.8\%.

The purpose of this study was to explore the relationship between metacognition and self-regulation on Civics subject at the eleventh grade social one class.

\section{Limitations}

A number of important limitations need to be considered. Although the study reached some significant conclusion, some limitations exist. This research was conducted limited in SMAN 1Cerme. If carried out at different places likely outcome is not the same.

\section{Conclusion}

Based on research that has been conducted and analyzes that have been raised can be concluded that any the close relationship between metacognition with self-regulated learning. Test the correlation between the variables metacognition and self-regulated learning of students in the materials administration I Civics class X IPS-1 SMAN 1 Cerme, obtained correlation index $r_{x y}=0,799$ so the correlation is strong. And the influence of students' metacognition towards self-regulated learning, the value of $r_{2}$ of 0.638 . Then the value is multiplied by $100 \%$ to determine the influence in a percent value. Thus obtained value of the influence of students' metacognition on self-regulated learning in class XI IPS-1 SMAN 1Cerme 63 8\%.

\section{References}

Aliaga and Gunderson. 2005. Interactive Statistics, 3rd Edition. New Jersey: Prentice Hall.

ASTM.2012. Standards C1754/C1754-12, Standard Test Method for Density and Void Content of Hardened Pervious Concrete,ASTM International.

Azevedo, R. Aleven, V. 2013. International Handbook of Metacognition and Learning Technologies. New York: Springer.

Beran, M J., Brandl, J.L, Perner. J. \& Proust, J. 2012.Foundation of Metacognition. $\quad$ United $\quad$ Kingdom: $\quad$ Oxford University Press.

Bless, Claire.,\& Crag Higson-Smith. 2000. Fundamental of Social Research Methods:An African Perspective. Cape Town: Juta.

Boyd, J, Barnett, S.W, Bodrova, E, Leong, DJ, \&Gomby.D., 2005.Promoting Children's social and Emotional Development through Preschool Education.National Institute for Early Education Research Preschool Policy Brief.New Brunswick, NJ: Rutgers. Retrieved October 25, 2016, from www.nieer.org. 
Desoete, A. 2008.Multi-Method Assessment of Metacognitive Skills in Elementary School Children: How You Test is What You Get. Springer.

Handel, M., Artelt, C., \&Weinert, S. 2013. Assessing Metacognitive Knowledge: Development and Evaluation of a Test Instrument.Journal for Educational Research Online Volume 5 Waxmann.

Hashempour, M., Ghonsooly, Behzad; Ghanizadeh, A. 2015.A Study of Translation Students' Self-Regulation and Metacognitive Awareness in Association with their Gender and Educational Level.InternationalJournal of Comparative Literature\& Translation Studies.

Hergenhahn, B.R, \& Olson, M.H. 2015.Theories Of Learning. Upper Saddle River, NJ: Prentice Hall.

Josyula, D.P, Franklin. C.H, Harish V, Bette J.D, Fassil M., Michelle, Ahmed K.,\&ChinomnsoM.2013. Metacognition for Self-Regulated Learning in a Dynamic Environment.

Krathwohl, D.R 2002.A Revision of Bloom's Taxonomy: An Overview. The Ohio State.

Lai, E. R. 2011.Metacognition: A Literature Review-ResearchReport.Pearson.

Likert, Rensis. 1932. A Technique for the Measurement of Attitudes, Archives of Psychology, 140:1-55.

Louca, E. P. 2008. Metacognition and Theory of Mind.Newcastle UK: Cambridge Scholars.

Mohamed, A.H.H. 2012.The Relationship berween Metacognition and Self Regulationin Young Children. Elsevier Ltd.

Pintrich, P.R., Wolters, CA, \& Baxter, G P. 2011.Assessing Metacognition and Self-Regulated Learning Issues in the Measurement of Metacognition.Paper 3.

Tzohar-Rozen M, Kramarski, B. 2013.Metacognition, Motivation, and Emotions: Contribution of Self-Regulated Learning to Solving Mathematical Problems.

Veenman, M.VJ, Wolters, B. H.AM, Afflerbach, P. 2006. Metacognition and Learning: Conceptual and Methodological Considerations. Springer.

Velzen, J.V. 2016.Metacognitive Learning-Advanced Learning by Developing General Knowledge of the Learning Process. Amsterdam: Springer.

Woolfolk, A. 2009.Educational Pshychology Active Learning Edition.Boston: Allyn and Bacon. 